\title{
Three evils of citizenship education in Turkey: Ethno-religious nationalism, statism and neoliberalism
}

\author{
Relying on a theoretical frame developed in reference to an interdisciplinary \\ research field, this article provides a critical analysis of Turkey's citizenship \\ education (CE) curriculum with a view to revealing discourses that inhibit the \\ promotion of cosmopolitan values of human rights, democratic citizenship and \\ diversity. The analysis demonstrates that a complementary set of ethno-religious, \\ statist and neoliberal discourses undermines the cosmopolitan values. The \\ inharmonious patchwork of these two sets of conflicting discourses raises the \\ question of whether CE in Turkey really empowers students to support \\ democracy. This question reveals the significance of developing a CE curriculum \\ underpinned by a consistent set of socio-political values in Turkey and elsewhere.
}

Keywords: citizenship education; social studies education; national identity; nationalism; human rights; cosmopolitan citizenship; neoliberalism; textbooks; diversity; Turkey.

\section{Introduction}

Citizenship education (CE) has a high rhetorical value in educational reform discourse. Despite differences resulting from a widely-held belief that citizenship curriculum is developed through compromises, it now stands as an established subject which aims to provide young people with knowledge, values and skills essential to support democracy and human rights (Kennedy, 2019; Osler \& Starkey, 2005). However, CE has come to be recognised as such after a gradual process of transformation in time. Offered since the 1890s, citizenship courses have had changing names, curricular status and content in the United States (Ahmad, 2017). Traditionally constitution and state-centric content of these courses turned into a form in which the normative values of liberal democracy, justice, diversity and equality eventually became prominent. In France, citizenship courses have been offered since the 1880s, and their curricular status and content underwent a similar transition to that of the USA (Osler \& Starkey, 2009; Soysal \& 
Szakács, 2010). Republican constitution-centric content of these courses shifted to emphasise human rights, diversity and cosmopolitan perspectives. Despite its relatively young age in England, citizenship curriculum was revised in 2008 to better address the ethno-cultural diversity of the country's population.

The transformation of $\mathrm{CE}$ in major western countries alludes to the fact that the nationalist model of $\mathrm{CE}$ is now widely seen as outdated and irrelevant to the needs of increasingly multicultural educational spaces (Banks, 2008; Osler \& Starkey, 2018). The insufficiency of nationalist CE led several scholars to propose new models that better address the changing socio-cultural and political landscape and prepare young people for their future roles as citizens. Some of the proposed models identified two prominent orientations for CE: participatory and justice-oriented (Westheimer and Kahne, 2004), some centred on diversity and intercultural dialogue (Banks, 2008), while some addressed skills for discussion and deliberation (Hess \& McAvoy, 2015; Parker, 2003). Among the new models, education for cosmopolitan citizenship offers a persuasive response to the contemporary educational conditions characterised by an intensifying level of interconnectedness (Osler \& Starkey, 2005; Osler \& Vincent, 2002). It strives to realise a vision of good society in which people of diverse opinions and identities interact, live together peacefully and learn from each other.

While 'education for an exclusive national citizenship' is prone to producing alienation and greater inequalities, education for cosmopolitan citizenship supports the values of human rights, democratic citizenship and diversity (Osler \& Starkey, 2018, p. 32). Instead of using education as homogenising machinery that imposes the values of powerful groups, education for cosmopolitan citizenship seeks ways to dismantle barriers to equal participation of disadvantaged and marginalised identities. Respect for diversity and learning from others symbolise the defining characteristics of education 
for cosmopolitan citizenship. An educational environment promoting cosmopolitan citizenship enables young people to develop their skills for political efficacy and freely negotiate their multiple loyalties and belongings. In such settings, students and teachers feel safe to express their differences in the hope that their diverse values and identities will be respected and flourish through interaction with other people.

The present study draws on concepts and ideas from the theory of education for cosmopolitan citizenship partly because I find it as the best model addressing the sociopolitical conditions of Turkey. In more specific terms, education for cosmopolitan citizenship can alleviate educational issues that emanate from the dominating nationalistic mindset and advance Turkey's goal to become a respectable country that contributes to the development of a universal culture of human rights. A commitment to education for cosmopolitan citizenship can also unleash the potential of national education in improving Turkey's relations with the Council of Europe and the United Nations (UN) and advancing its membership application to the European Union (EU). Although the theory of education for cosmopolitan citizenship is promising, it has not been fully put into practice in educational systems around the world. It is a fact that some countries' curricula intensely contain the vestiges of nationalistic $\mathrm{CE}$, but the neo-institutionalist studies of Stanford University concluded that textbook-attributions to human rights and diversity increased in an international scale since the end of World War II (e.g. Bromley, 2009; Ramirez, Bromley, \& R_ussell, 2009). Nevertheless, there is still little evidence on how old discourses of nationhood are integrated with the relatively newer discourses of human rights, democratic citizenship and diversity. As underlined by Bromley (2011), the transition from traditional to a newer form of CE is not linear, but 'there is a complex interaction between old and new' (p. . $_{-} \underline{5} 3$ ). This complex entanglement has been investigated in several in-depth studies (e.g. Bromley, 
2011; Choi_\&_Kim, 2018; Oșler \&_ Stararkey,_2009;_Soys_al_\&_Szakakács 2 2010). Following this literature, this article examines Turkey's social studies education (SSE) textbooks in use to reveal discourses that undermine the cosmopolitan values. By showing complications with the promotion of cosmopolitan values, I hope to contribute to efforts in re-imagining schools 'as spaces of democratic conviviality' (Levinson, 2011, p. 292). The identification of discourses that impede the acquisition of the cosmopolitan values may contribute to CE scholarship by providing insights for those who attempt to strengthen the capacity of CE to serve the realisation of cosmopolitan ideals.

The article is organised according to the argument of the study that the discourses of ethno-religious nationalism, statism and neoliberalism undermine the cosmopolitan values in the SSE textbooks. To provide a context for this conclusion, I start with a discussion on how nationalist, statist and neoliberal discourses theoretically stand in tension with the notion of cosmopolitan citizenship. After presenting the historical background of CE in Turkey, the article proceeds with an account of the textbook analysis and the different discourses identified then a concluding discussion.

\section{Cosmopolitan citizenship, nationalism and neoliberalism}

The intellectual roots of cosmopolitanism lie in the ethical reasoning of the liberal Enlightenment Europe tradition. It refers to thoughts and actions supporting the emergence of a world society in which people of diverse identities live together peacefully with their multiple belongings and identities in their multi-layered communities (Held, 1997; Nussbaum, 1996). The Universal Declaration of Human Rights (UDHR) is premised on a value consensus that is expected to bring humanity closer to the cosmopolitan vision of one human family (Starkey, 2012). The upholding of progressive principles of human rights, democratic citizenship and diversity is key to the realisation of cosmopolitan ideals. Cosmopolitanism may be contentious in some 
policy areas but, under the conditions of increasing world interconnectedness, the ideal of raising citizens who are willing to live together with others and learn from their differences appears as a valid and powerful educational objective.

Citizenship defined as equal membership to a political community is closer to cosmopolitanism as compared to nationalism. However, this liberal definition of citizenship is rarely put into practice because nation-states still represent the prominent political structure in which the notion of national citizenship functions as the prime tool for ensuring state legitimacy. In nation-states, what is often prioritised are certain collective identities against the equalising logic of citizenship, so not all are regarded as equal citizens, but some are privileged over others. This points to a contingent tension between the notions of national identity and citizenship. Levinson (2011) alludes to this tension by underlining that citizenship is often a parcel of democratic regimes, whereas authoritarian governments give more priority to the notion of national identity.

Leading scholars of nationalism highlighted that nationhood is a socially constructed state of mind as opposed to the essentialists who viewed nations as natural entities existing from immemorial times (e.g. Anderson, 2006; Smith, 2008). The constructivists underlined the role of intelligentsia, education, industrial revolution and printing technologies in the discursive construction of nationhood. First proposed by Kohn ([1944]_2017), two models are widely used as heuristic devices in analysing the formation of nationhood: civic-territorial and ethno-genealogical models. The former is seen in developed western nations where all people are regarded as equal citizens of a rationally organised society. In such societies, strong institutions and a developed civic culture ensure state legitimacy by enabling people to develop a feeling of belonging to their communities. The latter model is seen in contexts where industrial infrastructure, institutions and civic culture are absent or weak. In such contexts, primordial ties of 
kinship and religion are used as a source of state legitimacy. Emphasis on primordial ties and exaltation of the ancient greatness of nation is anticipated to compensate for the weakness or absence of a functioning economy, institutional order and civic culture.

While the ethno-genealogical model is exclusionary, because it omits the principle of equality, one of the defining tenets of citizenship, the civic-territorial model is not neutral from a critical perspective. Non-Christians, non-Westerns and non-whites may find it extremely modernist, white-centric and aligned to a Christian culture (Kymlicka, 2018; Parekh, 1998). Secondly, associating the civic model with developed western countries and the ethnic model with non-western countries purports an orientalist view (Jaskułowski, 2010). As these criticisms demonstrate, these models of constructing a sense of nationhood are not very compatible with the notion of citizenship. A liberal model may suggest that it is sufficient to become a nation when the members of a political community believe that they belong together and come from 'a common history and look forward to a common future" (White, 1997, p. 15). However, this liberal model is a rare example since those in the position of power (with an ideological agenda) often favour exclusive national identities, as the perpetuation of their privileges entails suppressing those who struggle for equality and justice.

The unspeakable human tragedies of World War II starkly exposed the negative implications of exclusive nationalisms, which fuelled post-war efforts to promote a universal culture of peace and human rights. Against the backdrop of imposing exclusionary national identities, the post-war era favoured the removal of hierarchical inequalities between diverse sexual, ethnic, religious and racial identities. The widespread acceptance of human rights supported the consolidation of inclusive national identities. Kymlicka (2018) uses the term "citizenisation" in referring to the spread of rights struggles in this era, such as the decolonisation, civil rights and 
minority rights movements (p. 100). These struggles are guided by a vision that people regardless of their differences can live together in diverse democratic societies. This facilitated the integration of discourses of human rights and democratic citizenship into social education curriculum especially after the end of Cold War. In contemporary world order defined by the phenomena of global migration and technological advancements, the post-war project of 'citizenisation' continues despite the fact that farright nationalists once again express essentialist ideas that nationhood is closed, natural and primordial. These ethno-religious discourses that loudly resonate in political discourse now oppose the inclusion of 'others' with an anti-elitist rhetoric that wealthy and educated classes betray national interests.

While revitalising ethno-religious discourses run contrary to democracy and human rights values, neoliberal discourses also prolongate negative effects on the ideal of cosmopolitan citizenship. For McChesney (1999), neoliberalism 'refers to the policies and processes whereby a relative handful of private interests are permitted to control as much as possible of social life in order to maximize their personal profit' ( $\mathrm{p}$. 7). Neoliberalism as a concept of economy differs significantly from classical liberalism (Harvey, 2005). While classical liberalism advocates minimal state intervention and fair competition in market relations, neoliberalism recognises the state as the main regulator, enabler and promoter of market relations. It encourages to utilise state power in creating conditions in which public services like education, health and security can be provided by private companies. Davies \& Bansel (2007) explains:

The 'social state' thus gives way to the 'enabling state', which provides individuals with the knowledge, powers and freedoms to take care of themselves. The state, in this new belief system, can (and should) no longer be responsible for providing all of society's needs for security, health, education and so on. Individuals, firms, organizations, schools, hospitals, parents and each individual must all take on (and desire to take on) responsibility for their own well-being (p. 251). 
The retreat of the state from public services through the responsibilisation of non-state actors is guided by a conviction that free market logic will yield the most optimal outcome. This conviction transforms the view of education from a common good to a commodity (Apple, 2006). The growing popularity of school performance rankings and standardised tests are indicators of the installation of consumer-oriented market logic into public education. Prevailing discourses of economic accountability and choice reconstruct students as consumers and teachers as providers of education service (Biesta, 2004). These discourses allow 'consumers' to enjoy a shallow rather than substantive engagement with the quality of education. Furthermore, the imposition of neoliberalism as the given and inevitable system compels educators to cultivate competitive entrepreneurial subjects who aspires to become a good player in the transactional relations of global economy (Rizvi, 2009).

The prevalence of neoliberalism in education poses two major threats to education for cosmopolitan citizenship. First, by encouraging to place gaining a material reward at the centre of individual motivations, it undermines the acquisition of nonmarket values of equality, justice, altruism, solidarity and collective action. Secondly, by widening socio-economic inequalities between social classes, it reduces the chances of marginalised people to participate meaningfully in public life. Overall, neoliberalism exacerbates inequalities by putting the vulnerable at the hands of market capitalism and erodes the possibility of a cosmopolitan dialogue across differences in society.

In summary, the intense level of interconnectedness in the contemporary world requires the promotion of cosmopolitan citizenship more than ever despite the fact that nationalist and neoliberal discourses continue to erode the foundation of cosmopolitan citizenship by perpetuating inequalities and hierarchies. The next section will expand on how these ideas are manifested in public discourse in Turkey. 


\section{Development of ethno-religious nationalism and neoliberalism in Turkey}

The Turkish term for citizenship vatandaşlık or yurttaşlık is a derivative of the word vatan or yurt meaning homeland or motherland. The etymological root of vatandaşlık has an important difference from its English counterpart. While citizenship is related to a smaller polity of city, vatandaşlık is associated with a larger polity of homeland. This etymological difference suggests that vatandaşlık is more associated with nationalism as it was devised as a formula to prevent the disintegration of the Ottoman state. The term later became central to the modernisation project after the Republic of Turkey succeeded the Ottoman Empire in 1923. In the state formation era (1923-1938), the founding figures under the leadership of Mustafa Kemal Atatürk (Atatürk hereafter) were bent on promoting a secular Turkish identity (Zürcher, 2004). In the project of building a secular nation, the terms for Turkish national identity and citizenship took on close meanings as both concepts were used interchangeably in referring to the identity formation of modern-secular citizens or Turks who could maintain their lives by rationality rather than irrational beliefs and superstitions.

The cultivation of such citizens by education was perceived as the antidote to economic underdevelopment and socio-cultural backwardness. Moulding differences into a unified common identity, namely the Turkification of diverse inhabitants of Anatolia, was seen key to the survival of the state. In the 1930s, religion was no part of the curriculum, and girls were co-educated in mixed classrooms. In accordance with the notion of laicite, which 'mandated no religion in governmental affairs, politics or education', educational institutions discouraged any talk of diversity (Çağaptay, 2020, p. 1). The republican logic of difference-blindness and equality before the law signified the backbone of the official citizenship theory, but in the practice of everyday cultural and religious life, the ethno-religious identity of Sunni-Muslim is regarded as the chief 
marker of Turkish identity (Bayır, 2013). From the 1920s on, the civic terminology used in legal texts turned into a cover for Turkification.

The initial formulation of citizenship in the 1840s Ottoman Empire was different from the later-emerging notion of ethno-religious citizenship. The 1876 Constitution recognised all inhabitants of the land as 'Ottoman citizens' regardless of their diverse ethno-religious identities. However, this citizenship theory was discontinued by the following nationalist project which replaced the descriptor 'Ottoman' with 'Turkish' in the citizenship law in 1924 (Lord, 2018). Afterwards, all people who are bound to the state with the tie of citizenship are named Turkish. The 1923 Lausanne Treaty guaranteeing Turkey's independence took the religion as the criterion to distinguish Turkish from non-Turkish people. From this legacy on, the official theory of national identity inseparably interwove Turkishness with Sunni-Islam. An experienced journalist Fikret Bila, who has been to the entourage of former Prime Minister Binali Y1ldırım during an official visit to the autonomous Gagauzia region of Moldova, shared his bewilderment at seeing Turkish-speaking Christian children playing on a Church's playground: 'They were speaking a very good, very pure, and very fluent Turkish... Yet, they were not Muslim' (Bila, 2017). Bila's amusement comes from the entrenched belief that Turkish identity cannot be preserved in the event of conversion from Islam.

The notion of ethno-religious national identity became more entrenched after the transition to multi-party democracy in 1950 . This resulted in the revision of secularist policies in favour of expanding time, space and content of Islamic education. In the 1950s, secular-track schools began to offer Islamic education courses, and new schools were opened to raise a clergy for religious services. The fight against communism and neoliberal policies following the 1980 s provided a conducive context for this shift to Islamisation (Blad \& Koçer, 2012). The 1982 constitution made Islamic education 
courses compulsory from fourth grades onwards without exemption. One particular organisation, the Intellectual Hearth, convinced the coup leaders to adopt the Turkish Islamic Synthesis (TIS) programme developed by the Hearth, which envisaged to augment the role of mosque, military and family as governmental control devices (Lord, 2018). This accelerated pace of Islamisation culminated in the rise of political Islamist Welfare Party (WP) in the 1990s (Çağaptay, 2020). Even though the WP faced the suppression of militant-secular forces, Justice and Development Party (JDP), splintered from the political Islamist movement, came to power in 2002. Remaining in power since then, the JDP has fundamentally transformed the traditional state policies.

While most of its key politicians were religiously conservative figures, the JDP was initially perceived liberal against the backdrop of repressive Kemalist state legacy. Emerged as a 'conservative democrat party' with an agenda of making Turkey a member of the EU, the JDP has gone through many critical milestones. By 2010, it was presented as a model to authoritarian Muslim-majority countries. However, the precipitous transformation of Arab Spring into Arab sorrow, the break-out of Gezi demonstrations in Turkey, and the military toppling of Islamist Morsi government in Egypt all made Erdoğan suspicious of a foreign conspiracy that his fate could follow suit. This led him to strengthen his grip on power following the brutal suppression of Gezi Park demonstrations in 2013. Since then, Turkey's image in the international arena has changed from being a secular European to an Eastern Muslim nation as its international alliance shifted towards the eastern bloc of Russia, China and Iran (Çağaptay, 2020). The crucial moment in this shift was the 15 July failed coup attempt in 2016. Once a pivotal ally of Erdoğan, cleric Fetullah Gülen's followers who occupied critical posts in civil and military bureaucracy allegedly masterminded a coup attempt. Subsequently, the state purged its tens of thousands of employees on the charges of 
being involved in Gülenism, and by a referendum, the parliamentary democracy was turned into a strong-executive presidency in 2017.

After President Erdoğan declared 'raising a religious generation' as the goal of education in 2012, the curricular time of Islamic education courses, the number of Islamic schools and number of students in these schools reached their all-time peak. In parallel, neoliberal policies made themselves evident in education as the ratio of private schools hiked to 19.2 per cent in 2019, which was around 2 per cent by 2002 (Ministry of National Education [MoNE], 2019). Now, students enrolled in private schools make up the $8.7 \%$ of the entire student population, which was around $1.6 \%$ by the time the JDP came to power in 2002 (Cinoglu, 2006).

In the current socio-political context, an alliance between the JDP and the Nationalist Movement Party rules the country. Against the backdrop of a downturn in the economy, worsening relations with the western bloc, and increasing security risks in the region, the soft-power diplomacy of the early JDP governments has turned into a military power-driven diplomacy. Turkey is now a host to 'the largest number of refugees worldwide, with close to 4.1 million refugees' (UN, 2020). Although the increasing presence of refugees further diversifies the student population, the MoNE still pursues a nationalistic model of CE. A comprehensive textbook study concluded that ethno-religious, statist and militarist perspectives prevailed in textbooks from primary to high school (Çayir, 2014). This study proposes that a commitment to education for cosmopolitan citizenship can be an effective response to educational issues resulting from the dominating nationalistic mindset. With this conviction, this article seeks an answer to the following question: which discourses can be identified in Turkey's SSE textbooks that undermine the cosmopolitan values of human rights, democratic citizenship and diversity? 


\section{Analysing textbook discourses}

The reason for choosing to analyse SSE textbooks is that SSE now represents the curricular space where CE features most prominently in the Turkish middle school curriculum. The analysed textbooks are the ones which are centrally produced, controlled, distributed and compulsorily taught across the country:

1. Tüysüz, S. (2018). Sosyal bilgiler ders kitabı 4 [Social studies textbook 4]. Ankara: Tuna Matbaacilik.

2. Şahin, E. (2018). Sosyal bilgiler ders kitabr 5 [Social studies textbook 5]. Ankara: Anadol Yayınc1lık.

3. Yılmaz, F. G., Bayraktar, H., Özden, M. K., Akpınar, M., \& Evin, Ö. (2018). Sosyal bilgiler ders kitabı 6 [Social studies textbook 6]. Ankara: Devlet Kitapları.

4. Gültekin, G., Akpınar, M., Nohutcu, M., Özerdoğan, P., \& Aygün, S. (2018). Sosyal bilgiler ders kitabı 7 [Social studies textbook 7]. Ankara: Devlet Kitapları.

Partly because the study aimed to identify discourses that run against the cosmopolitan values, it is framed as a qualitative study which employs document analysis as the main mode of inquiry (Bowen, 2009). For the same reason, it adopted a combination of content and discourse analytical approach for textbook analysis. The objective of the study guided textbook analysis as I coded all discourses which I found undermining the mentioned cosmopolitan values. Then, I sorted the coded passages into categories and undertook a close textual analysis drawing on the conventions of critical discourse analysis (CDA) (Fairclough, 2010). CDA is a discipline within the field of applied linguistics which aims to reveal linguistic strategies employed in the discursive legitimation of dominant ideologies. My reliance on CDA is rather instrumental since my objective is to identify discourses that eclipse the potential power of CE. CDA is an apt tool for this research partly because power relations in the wider society get 
embodied in textbooks (Apple, 2004). Textbooks are cultural products reflecting the dominant values of time and space in which they are produced. What is conveyed in them play a central role in making certain perspectives legitimate and some, illegitimate and marginal. Representing the most commonly used curricular resource, the SSE textbooks codify system-level expectations that guide citizenship learning experience of young people. For these reasons, CDA is a useful critical lens to identify ways in which the powerful groups are represented with their positive characteristics and disadvantaged groups are represented with their negative characteristics or ignored altogether in the textbooks. The subsequent three sections present the identified textbook discourses of ethno-religious nationalism, statism and neoliberalism.

\section{Ethno-religious nationalism}

Ethno-religious nationalism became more evident in the textbooks after the 1980 coup (Üstel, 2004). The national curriculum is still informed by an exclusionary citizenship theory privileging the values of Sunni-Turkish majority (Çayir, 2014). This continues in the analysed textbooks as they discourage expressions of cultural diversity but present the values of Sunni-Muslim majority as though they belonged to the whole nation. One textbook explains the concept of diversity and identity by focussing on individual-level differences, such as fingerprint, face, way of walking, heartbeat, being calm, careful, scrupulous, messy, shy or sociable (Tüysüz, 2018, p. 11). The same textbook includes a section on Kasımiye Madrasah in Mardin, a multicultural city in southeast Turkey (pp. 41-42). In this section, madrasahs are praised and described as components of 'our' cultural heritage. Even though Mardin has non-Muslim inhabitants and non-Islamic cultural sites, the textbook gives no clue about them.

One textbook underlines that: 'the unifying power of Islam strengthened our social cohesion by affecting our national culture' (Y1lmaz et al., 2018, p. 18). In line 
with this view, the textbooks describe religious-cultural practices of Sunni-Turkish majority, such as joining Eid prayer in a mosque, kissing elderlies' hands in religious festivals and organising circumcision ceremonies, as national cultural practices (Tüysüz, 2018, p. 38- 43; Y1lmaz et al., 2018, p. 17). In a similar vein, historical scholars of Islamic worlds are depicted as though they all were of Turk-Islam origins (Gültekin et al., 2018, pp. 134-141). One textbook refers to Prophet Muhammad as 'our prophet' (Y1lmaz et al., 2018, p. 57-61), while the others contain many visuals of mosques, minarets, religious scholars, shrines and lodges (Gültekin et al., 2018, p. 14-38-86-87169-212; Tüysüz, 2018, p. 16-17-42; Y1lmaz et al., 2018, p.18-38-67-74-81). An Islamic history narrative of Prophet Muhammad, the four caliphates and the first Muslim states fortifies this ethno-religious construction of the 'national culture'.

The Turkish history narrative follows an ethno-genealogical line from the migration of Turkic clans from Central Asia to Anatolia. It sends a message that Turkish people came to Anatolia from outside, have not interacted with ethno-religious residents of the land and remained 'pure'. This ethno-religious discourse is crystallised in a distinction between coming from the same genealogy [soydaş] and being a citizen of Turkey [vatandaş] (Tüysüz, 2018, p. 183). By these terms, a genealogical link is established with ethnic Turks living outside Turkey who are not citizen of Turkey.

While the textbooks present Sunni-Islamic beliefs and practices as belonging to the whole nation, they also place non-Muslims under a negative light:

\footnotetext{
Our president released a Ramadan Eid message. In his message, he said: 'we reached the Eid by leaving behind the month of Ramadan, whose beginning is mercy, midpoint is forgiveness and end is salvation from eternal suffering. I congratulate with all my heart and soul your holy Ramadan Eid. For the duration of the month, we lived together a climate of a big brotherhood, solidarity, togetherness and helping each other. I wish the Eid will bring peace, happiness and tranquillity to all hearths, houses, our country and Islamic world'. Our President
} 
released a Christmas message. In his message, he said: 'I wish Christmas, which our Christian citizens belonging to different creeds, traditions and churches, celebrate following their own beliefs, will contribute to the improvement of the climate of helping each other and solidarity, I congratulate firstly our Christian citizens' and the whole Christian wold's Christmas' (Gültekin et al., 2018, p. 207).

The president's messages to the two different communities of Turkey manifest an 'us versus them' dichotomy. In the Ramadan message, the president invokes the pronoun 'we' by including himself in the community of believers who observe the holy month of Ramadan. While the Ramadan message does not mention the religious identity of those who observe it, the Christmas message addresses 'our Christian citizens'. The president uses the expression 'our Christian citizens' with a linguistic marker, 'their own belief', to distance himself from the Christian community. Secondly, those who celebrate the Eid are not represented with the possessive pronoun 'our', whereas those who celebrate Christmas are described as 'our Christian citizens'. The possessive noun 'our' before 'Christian citizens' situate them at a lower status. Lastly, the Ramadan Eid message warmly emphasises the unity, solidarity and brotherhood as though there was a unified Islamic world with no sectarian division. In contrast, the Christmas message highlights the disunity within the Christian community by phrases 'different creeds, different traditions and different churches'. However, despite these ethno-religious discourses, the inclusion of the president's Christmas message may be seen as a step forward considering that diversity is customarily not recognised in textbooks.

\section{Statism}

The textbooks present no public institutions, no branch of the government and nothing associated with the state in a critical light. The following news titles show the positive representation of state: 'Pre-school education for agriculture workers' children'; 'Vaccination campaign by the Health Ministry for Guest Children' (Şahin, 2018, p. 28); 
'The Ministry of National Education will distribute 190 million free textbooks';

YADES (Elderly Support Programme) (Gültekin et al., 2018, p. 208); 'The first aid to Mosul is from Turkish Red Crescent' (Tüysüz, 2018, p. 123). These news titles present the state as an embodied symbol of altruism that always takes care of its citizens' needs. Even the issues of refugee students are narrated to glorify the goodness of the state. For example, a Turkish student reflects on her encounter with refugee students as follows:

Our state thought of their nutrition, shelter and health needs along with their educational needs. With this purpose, it sent children of school age to schools and some of these children came to our school. In order to know closer these children who are guest in our country, I tried to speak to those who little learned Turkish. One of them told that they struggle in their classes because they do not know Turkish. However, s/he added that their teachers and classmates help them in this matter. Children with whom I talked told that they feel lucky since they are in Turkey... (Tüysüz, 2018, pp. 25-26).

The student's narration of the plight of refugee children depicts a picture of the benevolent and magnanimous nation-state by disguising the root causes of the problem.

The discourses of human rights, democratic citizenship and diversity find expression in the textbooks in an extremely abstract and de-contextualised manner. The articles of the UDHR and the Convention on the Right of the Child rarely appear, but they are not made accessible with relevant examples. The given examples are mostly from outside Turkey that seem to be chosen to represent the state in a favourable light:

Syria faced significant problems because of the civil war started in 2011. Since then, a part of Syrians, especially those who had lived in the regions close to our border took refuge in our country. Turkey ensured their life safety by opening its arms to hug its Syrian guesses and displayed a big example of humanitarianism by meeting their basic needs (Tüysüz, 2018, p. 181). 
In the excerpt, the state is personified as a welcoming host 'opening its arms' to hug its guests. The state with its hospitable nation takes care of refugee and immigrant children. The metaphor, 'guest', implies that Syrians will not stay in Turkey for good. This oft-used metaphor in the context of migration carries an exclusionary message that those who are considered as guests are supposed to leave the country at some point. 'Active Citizenship' unit starts with a paragraph emphasising that the state authorities perfectly meet all basic necessities of its citizens (Şahin, 2018, p. 154). The section contains the following sub-headings:

Institutions serving to meet our educational needs; Institutions serving to meet our health-related needs; Institutions serving to meet our transportation needs; Institutions serving to meet our security needs; Institutions serving to meet our justice needs; Institutions serving to meet our correspondence and communication needs; Institutions serving to meet our shelter-housing needs (pp. 154-158).

These sub-headings suggest that the state impeccably meets all the needs of citizens. A student reading such passages depicting an already perfectly functioning social system might rightfully ask, what is then the function or role of an active citizen? One textbook lists what is expected from an active citizen: voting when election time comes, paying taxes regularly, doing his military service, obeying laws and rules, acting with a sense of responsibility, contributing to the rule of the country, contributing to the economy of the country by producing and knowing his/her rights and using them when necessary (Şahin, 2018, p. 11). Duties look more prominent in the list which includes the term 'rights' only once and limits the invocation of a right with an ambiguous phrase 'when necessary'. The list suggests that the ideal citizen is one who obediently does what is told and contributes to the national development. In line with this, a learning activity lists the principles of democracy as equality, majoritarianism, national sovereignty, participation, pluralism and freedom (Y1lmaz et al., 2018, p. 188). 
Interestingly, the principles do not include the rule of law and human rights. This problematic conception is sustained in parts where democracy is depicted from a herocentric perspective as a regime founded by one single leader: 'Atatürk is the founder of both Republic and democracy in our country' (Gültekin et al., 2018, p. 202).

The attributions to the military coups are made in an extremely cautious, if not fearful, tone: 'In our country trying to make progress on the path of democracy and modernisation, some events that may damage that process happened. Especially, 1960, 1971 and 1980 military coups may be shown as an example of this' (Gültekin et al., 2018, p. 212). The modality 'may' relativize the fact that the military coups disrupted democracy by toppling the elected governments. This cautious tone dramatically changes when it comes to the latest coup attempt of 15 July 2016. The failed coup is described as a treacherous act of a group of terrorists who colluded with foreign powers. The resistance of people is praised as an exemplary act of patriotism, defending independence and democracy. Furthermore, 15 July is designated as 'Democracy and National Togetherness Day' (Şahin, 2018, p. 51). Nevertheless, sufficient details are not given about the identity of those who carried out the coup attempt. One textbook states that: "Some individuals who are the citizens of the Republic of Turkey founded an organization and betrayed our homeland for the sake of their interest" (Gültekin et al., 2018, p. 212). The author avoids calling the coup plotters as "Turkish", but "the citizens of the Republic of Turkey'. By invoking this expression, coup plotters who are referred to by ambiguous phrases are separated from 'genuine Turkish people'.

\section{Neoliberalism}

In the analysed textbooks, neoliberal discourses appear in harmony with ethno-religious and statist discourses in a way that educating competitive, entrepreneurial and designer individuals is regarded as a requirement of national development. To inspire students, 
the textbooks present the stories of successful entrepreneurs and designers and urge them to come up with entrepreneurial ideas and design new products (e.g. Gültekin et al., 2018, p. 120-213; Tüysüz, 2018, p. 187; Y1lmaz et al., 2018, p. 155). One textbook includes a topic entitled 'Leader Turkey' (Gültekin et al., 2018, p. 232) and presents the stories of successful entrepreneurs under the title of 'Qualified Person, Powerful Turkey’ (Gültekin et al., 2018, pp. 176-179). Another lays out the characteristics of an ideal entrepreneur as self-confident, innovative, curious etc., then lists the stages of putting a new business idea into practice (Şahin, 2018, p. 140).

The textbooks feature many statements from 'role-model' students whose thinking and actions are calibrated to support the neoliberal order. A student, who is good at drawing automobile designs, states that he sends his drawings to automobile journals (Tüysüz, 2018, p. 19). Another student promotes a product of his design: 'If you are complaining about your feet getting cold, I have happy news for you. With the new product I designed, your feet will never get cold. Do you wonder "how come"? Let me explain' (p. 111). Sounding like a TV commercial, the student's statements judge the value of an idea by its potential to yield economic profit. The same textbook equates a biological need with a psychological need, then presents 'fridge, washing machine, oven, soap and toothpaste' as though they were essential biological needs (p. 123). This neoliberal rationalisation arrives at a conclusion that 'people can become happy to the degree they satisfy their needs' (p. 124). Furthermore, students are encouraged to see themselves as consumers as a mother advises his son: 'Son, we are consumers. We buy products that are presented to us for sale and meet our needs with these products' (Şahin, 2018, p. 145). From this neoliberal angle, shopping is presented as an exciting activity (Tüysüz, 2018, p. 132) and a lengthy passage is included on preparing a family budget (pp. 138-142). Presenting 'shopping' and 'preparing a family budget' as 
something given and positive may be alienating for disadvantaged students who can afford neither of these activities in their family settings.

On very rare occasions, the textbooks contain statements from students who are interested in social responsibility projects. In a textbook, a student states that she came across an old woman with a disability struggling to ride her wheelchair on a disabledunfriendly sidewalk. After helping the woman, the student contemplates on what could be done to facilitate the lives of people with a disability and decides to 'start a plastic cap collection campaign in her school for those who cannot afford a wheelchair' (Tüysüz, 2018, p. 27). The student's campaign involves a matter which is supposed to be a basic state responsibility in a decent society. Thus, the student's campaign legitimises the relegation of a state's basic duties to charitable organisations on the neoliberal belief that it is not a state's duty to meet its citizens' healthcare needs.

\section{Conclusion}

This study furthers the main argument of the comprehensive textbook research project by concluding that the discourses of ethno-religious nationalism and statism as well as neoliberalism prevail in the current SSE textbooks in Turkey (Çayir, 2014). Far from promoting the cosmopolitan values, the textbooks promote neoliberal citizenship underpinned by ethno-religious values of dominant groups in power. Democratic citizenship and human rights discourses appear only in a tokenistic manner, and diversity goes totally absent. Moreover, statist discourses that prioritise the collective over the individual dominate the textbooks. This may be seen as an expression of the official desire to strengthen state legitimacy. However, the exaltation of the state as a sacred thing is likely to foster a set of attitudes associated with obedience and submission that are not defensible on either rational or ethical grounds. 
The analysed textbooks never bring up socio-political and economic inequalities to students' attention but offer a type of neoliberal social education that is likely to raise self-centric and greedy individuals. Unfortunately, the promotion of neoliberal discourses happens in a similar fashion in other countries (e.g. Choi \& Kim, 2018; Neoh, 2017). This cross-country similarity supports the critical educators' contention that a coalition of neo-conservative and neo-liberal forces dominate education policies in many countries (Apple, 2006). This trend of decline in the promotion of humanistic values may be challenged by giving more exposure to the current situation and making a convincing case that the values of human rights, democratic citizenship and diversity are vital to peaceful, democratic and decent living of diverse societies.

In England, the Labour government's effort to strengthen CE was associated with the goal of tackling institutional racism that was brought to public attention by the Stephen Lawrence Inquiry Report in 1999 (Gillborn, 2006). Despite favourable policy statements and political remarks, the content of CE curriculum did not address racism. Since it failed to deliver what it had promised to deliver, Gillborn (2006) described CE in England as 'a placebo', 'a fake treatment' and 'sugar coated pill' (p. 97). This type may correspond to personally responsible CE in Westheimer and Kahne (2004)'s taxonomy, which explains socio-political problems with individual faults by concealing their structural causes. This conservative model, which seems to dominate the SSE textbooks in Turkey, is anathema to new models that consider the acquisition of human rights as a minimum requirement for $\mathrm{CE}$.

In the past, the vision of good society that informed the ideal of educating good citizens was formulated in nationalistic terms in which the notion of self-rule warranted the teaching of nationalist citizenship. In the United States, for example, disputes over whose values would underpin public education were often settled in favour of 
sustaining the nationalist socialisation of young people (Salomone, 2001). Nevertheless, under the present circumstances, radical changes in society, such as the transformation of socio-economic relations with the emergence of the knowledge economy and rapid mobility of people across countries, have shifted the prevailing conception of citizenship from nationalistic to participatory, active and critical citizenship. Despite these fundamental shifts, this study shows that Turkey's SSE textbooks are still informed by a narrow nationalistic model of CE. This article proposes that education for cosmopolitan citizenship can be an effective response to this problem firstly because it can remove the identified discourses from the textbooks. Secondly, it can lead to the revision of ethno-religious history narrative and the recognition of diversity. Finally, it can offer students more opportunities to strengthen their political efficacy skills by holding democratic conversations on their identities, experiences and public issues. 


\section{References}

Ahmad, I. (2017). Citizenship education in the United States: A historical perspective. New York: Routledge.

Anderson, B. (2006). Imagined communities: Reflections on the origin and spread of nationalism. London: Verso.

Apple, M. W. (2004). Cultural politics and the text. In S. Ball (Ed.), The RoutledgeFalmer reader in sociology of education (pp. 179-195). London: RoutledgeFalmer.

Apple, M. W. (2006). Educating the 'right' way: Markets, standards, God, and inequality (2. ed). New York: Routledge.

Banks, J. A. (2008). Diversity, group identity, and citizenship education in a global age. Educational Researcher, 37(3), 129-139. doi: 10.3102/0013189X08317501

Bayır, D. (2013). Minorities and nationalism in Turkish law. Surrey, England: Ashgate.

Biesta, G. J. J. (2004). Education, Accountability, and the Ethical Demand: Can the Democratic Potential of Accountability Be Regained? Educational Theory, 54(3), 233-250. doi: 10.1111/j.0013-2004.2004.00017.x

Bila, F. (2017, May 8). 'Memleket için güzel bir iş yapmanın rahatlığı içindeyim' ['I am at the ease of doing something good for the country']. Hürriyet. Retrieved from http://www.hurriyet.com.tr/yazarlar/fikret-bila/memleket-icin-guzel-bir-isyapmanin-rahatligi-icindeyim-40450432

Blad, C., \& Koçer, B. (2012). Political Islam and state legitimacy in Turkey: The role of national culture in neoliberal state-building. International Political Sociology, 6(1), 36-56. doi: 10.1111/j.1749-5687.2012.00150.x

Bowen, G. A. (2009). Document analysis as a qualitative research method. Qualitative Research Journal, 9(2), 27-40. doi: 10.3316/QRJ0902027 
Bromley, P. (2009). Cosmopolitanism in civic education: Exploring cross-national trends, 1970-2008. Current Issues in Comparative Education, 12(1), 33-44.

Bromley, P. (2011). Multiculturalism and human rights in civic education: The case of British Columbia, Canada. Educational Research, 53(2), 151-164. doi: $10.1080 / 00131881.2011 .572363$

Choi, Y., \& Kim, Y. (2018). Deconstructing neoliberalism in global citizenship discourses: An analysis of Korean social studies textbooks. Critical Studies in Education, 1-16. doi: 10.1080/17508487.2018.1501718

Cinoglu, M. (2006). Private education as a policy tool in Turkey. International Education Journal, 7(5), 676-687.

Çağaptay, S. (2020). Erdogan's empire: Turkey and the politics of the Middle East. London: I.B. Tauris.

Çayir, K. (2014). Who are we? Identity, citizenship and rights in Turkey's textbooks. İstanbul: History Foundation Publ.

Davies, B., \& Bansel, P. (2007). Neoliberalism and education. International Journal of Qualitative Studies in Education, 20(3), 247-259. doi: $10.1080 / 09518390701281751$

Fairclough, N. (2010). Analysing discourse: Textual analysis for social research. London: Routledge.

Gillborn, D. (2006). Citizenship education as placebo: 'Standards', institutional racism and education policy. Education, Citizenship and Social Justice, 1(1), 83-104. doi: $10.1177 / 1746197906060715$

Harvey, D. (2005). A brief history of neoliberalism. Oxford: Oxford University Press. Held, D. (1997). Globalization and cosmopolitan democracy. Peace Review, 9(3), 309314. doi: 10.1080/10402659708426070 
Hess, D. E., \& McAvoy, P. (2015). The political classroom: Evidence and ethics in democratic education. New York: Routledge.

Jaskułowski, K. (2010). Western (civic) ‘versus’ eastern (ethnic) nationalism. The origins and critique of the dichotomy. Polish Sociological Review, (171), 289303.

Kennedy, K. J. 2019. Civic and citizenship education in volatile times: Preparing students for citizenship in the 21st century. Singapore: Springer.

Kohn, H. (2017). The idea of nationalism: A study in its origins and background. New York: Routledge.

Kymlicka, W. (2018). The rise and fall of multiculturalism? New debates on inclusion and accommodation in diverse societies. International Social Science Journal, 68(227-228), 133-148. doi: 10.1111/issj.12188

Levinson, B. A. U. (2011). Toward an anthropology of (democratic) citizenship education. In B. A. U. Levinson \& M. Pollock (Eds.), A companion to the anthropology of education (pp. 279-298). doi: 10.1002/9781444396713.ch17

Lord, C. 2018. Religious politics in Turkey: From the birth of the republic to the AKP. Cambridge, England: Cambridge University Press.

McChesney, R. W. (1999). Introduction. In N. Chomsky, Profit over people: Neoliberalism and global order (pp. 7-16). New York: Seven Stories Press.

MoNE. (2019, March 5). Resmi İstatistikler [Official]. Retrieved 5 March 2019, from the MoNE website: http://sgb.meb.gov.tr/meb_iys_dosyalar/2019_09/30102730_meb_istatistikleri_ orgun_egitim_2018_2019.pdf 
Neoh, J. Y. (2017). Neoliberal education? Comparing 'character' and citizenship education in Singapore and 'civics' and citizenship education in Australia. Journal of Social Science Education, 16(3), 29-39.

Nussbaum, M. C. (1996). Patriotism and cosmopolitanism. In J. Cohen (Ed.), For love of country: Debating the limits of patriotism (pp. 2-17). Boston: Beacon Press.

Osler, A., \& Starkey, H. (2005). Changing citizenship: Democracy and inclusion in education. Maidenhead, England: Open University Press.

Osler, A., \& Starkey, H. (2009). Citizenship education in France and England: Contrasting approaches to national identity and diversity. In J. A. Banks (Ed.), The Routledge international companion to multicultural education (pp. 334347). London: Routledge.

Osler, A., \& Starkey, H. (2018). Extending the theory and practice of education for cosmopolitan citizenship. Educational Review, 70(1), 31-40. doi: $10.1080 / 00131911.2018 .1388616$

Osler, A, and Kerry, V. 2002. Citizenship and the challenge of global Education. Stokeon-Trent: Trentham.

Parekh, B. (1998). Equality in a multicultural society. Citizenship Studies, 2(3), 397411. doi: 10.1080/13621029808420691

Parker, W. C. (2003). Teaching democracy. New York: Teacher's College Press.

Ramirez, F. O., Bromley, P., \& Russell, S. G. (2009). The valorization of humanity and diversity. Multicultural Education Review, 1(1), 29-54. doi: $10.1080 / 23770031.2009 .11102862$

Rizvi, F. (2009). Towards cosmopolitan learning. Discourse: Studies in the Cultural Politics of Education, 30(3), 253-268. doi: 10.1080/01596300903036863 
Salomone, R. C. (2001). Common education and the democratic ideal. In D. Ravitch \& J. P. Viteritti (Eds.), Making good citizens: Education and civil society (pp. 213232). New Haven: Yale University Press.

Smith, A. D. (2008). The cultural foundations of nations: Hierarchy, covenant and republic. Malden, MA, USA: Blackwell Pub.

Soysal, Y. N., \& Szakács, S. (2010). Reconceptualizing the republic: Diversity and education in France, 1945-2008. Journal of Interdisciplinary History, 41(1), 97115. doi: 10.1162/jinh.2010.41.1.97

Starkey, H. 2012. 'Human Rights, cosmopolitanism and utopias: Implications for citizenship education'. Cambridge Journal of Education 42(1):21-35. doi: 10.1080/0305764X.2011.651205

United Nations. (2020). Turkey | Global Focus [Org]. Retrieved 11 January 2020, from The UN Refugee Agency-Global Focus website: http://reporting.unhcr.org/node/2544

Üstel, F. (2004). 'Makbul vatandaş'ın peşinde: II. Meşrutiyet'ten bugüne Türkiye'de vatandaşlık eğitimi [In the pursuit of "good citizen": Citizenship education in Turkey from the Second Constitution to today]. İstanbul: İletişim Yayınları.

Westheimer, J., \& Kahne, J. (2004). What kind of citizen? The politics of educating for democracy. American Educational Research Journal, 41(2), 237-269. doi: $10.3102 / 00028312041002237$

White, J. (1997). National myths, democracy and education. In D. Bridges (Ed.), Education, autonomy, and democratic citizenship: Philosophy in a changing world (pp. 15-22). London: Routledge.

Zürcher, E. J. (2004). Turkey: A modern history. London: I.B. Tauris. 